\title{
Insect survey in the Vila Velha State Park, Brazil, in areas subject to fire action
}

\author{
Isabela Mendes Barzon ${ }^{*}$, Alexandre França Tetto ${ }^{*}$, Nilton José Sousa ${ }^{1 *}$, Bruna Kovalsykil ${ }^{*}$, João \\ Francisco Labres dos Santos ${ }^{1 *}$, Pietro Antonio Demoliner ${ }^{1 *}$
}

${ }^{1}$ Universidade Federal do Paraná, Curitiba, Brasil
*E-mails para contato: isabela.mbarzon@gmail.com, tetto@ufpr.br, nilton.ufpr@gmail.com,
bru_kovalsyki@hotmail.com, joaolabres@ufpr.br, pietroantoniodemoliner@gmail.com

\begin{abstract}
For the global understanding of the effects of fire on the environment it is necessary to analyze all the components associated with it, including insects as environmental indicators. Based on this premise, this study was carried out in Vila Velha State Park, southern region of Brazil, a 3,222.11 hectare integral protection conservation unit, created in 1953 to conserve native land, araucaria forest and arenaceous formations of scenic and scientific value. The objective of the study was to identify and compare the orders of insects found in a burned area in 2017. The collection and analysis period were 10 months, from June 2018 to March 2019, with collections every 30 days, with 15 traps of pitfall type in an area of 25 ha with predominance of grassy-woody steppe. For the calculation of the biological indexes, the data collected were processed in the ANAFAU program. The following orders were found: Blattodea, Coleoptera, Diptera, Hemiptera, Hymenoptera, Lepidoptera and Orthoptera. The Shannon-Weaner diversity index was 1.4179 (ranging from 1.0789 to 1.4019 in the monthly indexes) and the Equity index was 0.7914. The month of greatest abundance of the orders Hemiptera and Orthoptera was September (12 months after the passage of the fire), while Coleoptera, Blattodea, Diptera and Hymenoptera was December (15 months after the passage of fire); The order Lepidoptera showed dispersed abundance. The orders considered to be predominant were Diptera and Hymenoptera, due to the higher indexes of dominance (dominant and superdominant), abundance (very abundant and superabundant), frequency (very frequent and superfrequent) and constancy (constants). It can be concluded that the orders have specific times of greater occurrence and that the orders considered as environmental indicators are Diptera and Hymenoptera.
\end{abstract}

Keywords: Pitfall, Environmental indicators, Insecta 